\title{
MIESTO KOMPOZICIJOS SAMPRATOS KLAUSIMU
}

\author{
Tomas Grunskis \\ Architektūros pagrindu ir teorijos katedra, Vilniaus Gedimino technikos universitetas, \\ Pylimo g. 29/Traku g. 1, 01132 Vilnius, Lietuva \\ El.paštas grunskis@gmail.com \\ Iteikta 20100623
}

Santrauka. Analizuojant daug užsienio ir Lietuvos urbanistikos teorijos literatūros šaltinių ir urbanistinès erdvès (Urban Space) bei kompozicijos analizès pavyzdžių, pateikiamų šio straipsnio literatūros sąraše, apžvelgiamos ir analizuojamos urbanistinès (arba miesto) kompozicijos kategorijos, teorinès nuostatos bei sampratos. Šiame tekste pateikiami tarpiniai didesnio tyrimo rezultatai. Kai kurios jo tezès ir nuostatos buvo paskelbtos mokslinėse konferencijose bei mokslinèse publikacijose lietuvių ir anglų kalbomis.

Reikšminiai žodžiai: urbanistinè kompozicija, miesto kompozicija, meniniai urbanistikos principai.

\section{Ivadas}

Miesto kompozicijos objekto tyrimas yra nevienareikšmis ir gana sudètingas. Dažniausiai, nors ir skirtingai aiškinamas ir suprantamas, jis yra susijęs su estetiniais miesto struktūros bei erdvès klausimais ir net tokiomis grynojo objektyvumo ribas peržengiančiomis sąvokomis kaip grožis ir harmonija. Šie klausimai architektūrinèje ir menotyrineje analizèje yra daugiau objektyvizuoto atsakymo siekimas, naudojant vienokią ar kitokią analitinę matricą bei metodą, o su miesto kompozicijos problemomis yra kur kas sudetingiau. Šiandieninis miestas jau yra tapęs labai sudètingu ir daugiasluoksniu dariniu, kuriam yra būdingi fenomeno bruožai. Tai darinys, pakeitęs ir privertęs permąstyti daugelị iki šiol buvusių „kanonizuotų“ urbanistinių teorijų ir požiūrių i jị. Tai dinaminé nuolat kintanti ir savo forma, ir turiniu daugialypè sistema, susijusi su kitomis didesnemis urbanistinemis sistemomis, kurios formuoja didesnius urbanizuotus tinklus. Dèl šių ypatybių apie miestą ir jo estetiką jau nebegalima spręsti ir jị apibūdinti XIX ir XX a. kategorijomis. Šie klausimai ir problemos jau seniai peržengè vienos uždaros mokslinès srities ribas. Apie tokio darinio, XXI a. tapusio fenomenu, estetiką kalbèti ir ją analizuoti objektyviai bei produktyviai buvo ir yra labai sudetingas uždavinys, juolab kad kintant teoriniams požiūriams i̇ miestą, daugelis visa apimančių teorijų apie jo estetiką jau neberra aktualios. Tačiau pats miesto estetikos ir kompozicijos klausimas, turint omenyje globalines sociokultūrines sąlygas ir su jomis susijusią urbanistinę unifikacija, tebera aktualus. Panašiai, kaip jis buvo aktualus tiek Camillo Sittes (Зитте 1993) miesto formavimo meninès apologetikos laikais XIX a., tiek ir septintajame dešimtemtyje, kai kilo antimodernistinès urbanistikos teorijos banga, kurios atstovai buvo Jane Jacobs, Christofer Alexander (Alexander 1987) bei Kevin Lynch (Lynch 1960), ir vèliau, kai aštuntame dešimtmetyje buvo sukurtos tradicionalistinès miesto erdvès formavimo teorijos, kurios atstovai buvo broliai Leon ir Rob Krier (Krier, L. 1993, 2006; Krier, R. 1985, 1995, 2008). Šis klausimas yra aktualus ir šiandien, nes po sparčios urbanizacijos bangos per pastarąji dešimtmetị daugelis Lietuvos miestų, ir ypač sostinè Vilnius, ir „,iš išorès“ (miestovaizdžio aspektu) ir „iš vidaus“ (lokalaus vizualinio suvokimo aspektu) pakito itin smarkiai. Tai, ką Vakarų miestai pergyveno ir išdiskutavo per daugiau nei pusę amžiaus, Lietuvoje su nemenkomis klaidomis buvo realizuota per ne visus du dešimtmečius, ir tam realizavimui buvo pasitelkti 
gerokai senstelëję, o kartais ir nevisiškai aiškūs urbanistiniai konceptai, metodai bei požiūriai. Ir negalima būtų teigti, kad estetinis bei kompozicinis čia minimos transformacijos aspektai būtų kiek nors tinkami. Daugelis šiandien pasikeitusių Lietuvos miestų pavyzdžių rodo, kad estetinis bei kompozicinis klausimas kuriant ir naujai formuojant miesto centrus buvo menkai arba visai nepaisomas. Tenka pripažinti, kad čia dominavo kita - kur kas galingesne - komercinès naudos logika ir jai atstovaujantys socialinès galios subjektai. Tai, kad daugelio Lietuvos miestų kaitos rezultatai estetinio vaizdo prasme nèra geri, rodo, kad iki šiol nèra nei tinkamo požiūrio ị šị objektą, nei skiriamas tinkamas dèmesys šiam klausimui.

Analizuojant daug užsienio ir Lietuvos urbanistikos teorijos literatūros šaltinių ir urbanistinès erdvès (Urban Space) bei kompozicijos analizès pavyzdžių, pateikiamų šio straipsnio literatūros sąraše, siekiama apžvelgti ir paanalizuoti urbanistinès (arba miesto) kompozicijos kategorijas, teorines nuostatas bei sampratas. Šiame tekste pateikiami tarpiniai didesnio tyrimo rezultatai. Kai kurios jo tezès ir nuostatos buvo paskelbtos mokslinèse konferencijose bei mokslinèse publikacijose lietuvių ir anglų kalbomis.

Sąvokos miesto kompozicija ir urbanistine kompozicija šiame straipsnyje vartojamos sinonimiškai. Urbanistikos teorijoje jos labai dažnai siejamos su C. Sitte „meniniais miesto statybos pagrindais“ (Зитте 1993), miesto statybą šiame kontekste suvokiant kaip urbanistiką. Pernelyg nesigilinant i pačios urbanistikos sąvoką, kuri ligi šiol Lietuvoje gali būti suprantama skirtingai, pažymètina tik tiek, kad ją bendruoju atveju šiame straipsnyje suvoksime kaip „Urban Design“ atitikmeni, o C. Sitte požiūrị traktuosime kaip meninius urbanistikos arba miesto formavimo principus. Toks bendrinis požiūris atitiks ir vakarietiškas „Urban Design“ (Carmona 2003), ir postsovietines - rusiškąsias "Градостроительное искуство" (Яргина 1986) sampratas.

\section{Miesto kompozicijos ir estetikos vaidmuo urbanistikoje}

Bendruoju atveju urbanistines kompozicijos klausimai yra tiesiogiai susiję su miesto planinès ir erdvinès struktūrų estetika. Kadangi ir pačiu miestų, ir jų dalių dyžiai yra skirtingi, kompozicijos priemonès ir dèsniai juose irgi yra atpažistami skirtingai. Tačiau turint omenyje, kad, kalbant estetinemis kategorijomis apie miesto sandarą, labai dažnai sprendžiami skirtingo lygmens (arba mastelio) ir pobūdžio klausimai, urbanistine kompozicija apima visus šiuos lygmenis ir todèl esama skirtingų jos sampratų bei traktavimų. Jie gali būti ir subjektyvūs, ir objektyvūs. Subjektyvumo ir objektyvumo laipsnis, kai kalbama apie miesto struktūrą bei erdvę, bendruoju atveju parodytas 1 pav. Jis rodo, kad kuo didesnio mastelio yra (urbanistinis, architektūrinis ar dizaino) objektas (kūrinys), tuo mažiau subjektyvių aspektų jame yra, ir atvirkščiai, kuo objektas mažesnis, tuo daugiau jame yra meninès veiklos ir kartu subjektyvumo. Tik miesto lygmens (1 pav.) masteliu atsiranda aiškus meninès kūrybos

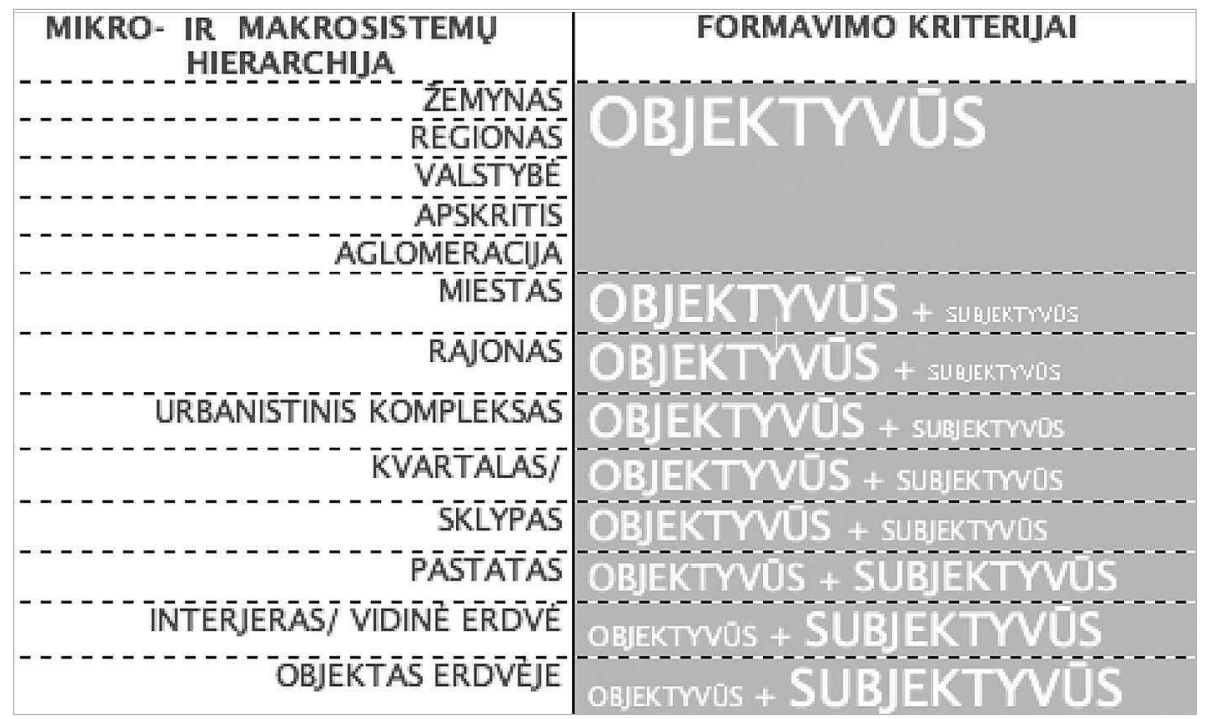

1 pav. Subjektyvumo ir objektyvumo santykis skirtingo mastelio sistemų hierarchijoje

Fig. 1. Relationship between the subjectivity and objectivity within the hierarchy of different-scale systems 
elementas bei subjektyvių vertinimo kriterijų ${ }^{1}$. Ir tai tokiais atvejais, kai mieste (tiek plano sandaroje, tiek erdvèje) gali būti atpažistami estetiniai kompoziciniai dèsningumai ir meninès kūrybos rezultatai. Dažniausiai - kuo miestas didesnis, tuo šie dèsniai atpažįstami sunkiau, o estetinis ir kompozicinis elementas bei jo analizė yra nelabai galima.

Remiantis apsibrèžta urbanistikos samprata, miesto kompozicija susijusi su erdve ir tūriu, net jei kalbame apie miesto plano kompoziciją, šie du dalykai urbanistikoje neturi būti ignoruojami. Ten, kur atsiranda labiau subjektyvumo kriterijais paremtos meninès kūrybos elementų, kuriant miesto erdvės kompoziciją ir ją analizuojant, paprastai irgi pasitelkiami objektyvesni požiūriai, kriterijai ir jų sistemos. Todèl tradiciškai bet kokia urbanistine kompozicija nèra visiškai subjektyvios kūrybos rezultatas.

Kita urbanistines kompozicijos sąvokos problemiškumo esmé yra ta, kad ne visais atvejais miestas buvo meninès kūrybos rezultatas. Toli gražu ne visais atvejais jis vystèsi planingai arba naudojant iš anksto parengtą planą. Tai labiausiai liečia ankstyvuosius ir viduramžių miestus, kurie vystèsi stichiškai ir natūraliai. Dažnai tokio miesto erdvinejje išraiškoje meninio formavimo požymiai yra labai reti ir sunkiai pastebimi. Tokio miesto formavimui konkretūs kompoziciniai ir meniniai dèsniai ar kanonai itakos nedaré, veikiau funkciniai, utilitarūs reikalavimai bei vietos (vietovès) sociokultūrinès charakteristikos - dislokacija gamtinio karkaso atžvilgiu, socioekonominès sąlygos ir pan. Tačiau beveik visais atvejais šiuose savaime susiklosčiusių miestų pavyzdžiuose atpažinsime savaiminès, natūralios raidos dèsningumus, kurie veike planinès struktūros susidarymo logiką, tačiau ar galètume tokius pavyzdžius pavadinti urbanistine kompozicija - tai vis dar yra diskutuotinas klausimas. Matyt, pagrindinis argumentas, svarstant šį klausimą, būtu estetikos ir kompozicijos santykis miestuose arba tai, kiek savaime susiklosčiusi miesto planinè ir erdvinè sandaros yra ar gali būti estetiškos, kai jų raidoje meniniai bei kompoziciniai dèsniai naudoti nebuvo. Ir atvirkščiai, aiškius kompozicinius dèsnius išreiškianti miesto struktūra ne visada yra estetiška tiek plano, tiek erdvinès sandaros aspektais (1 lentelè).

\footnotetext{
1 Bet kurią urbanistinę situaciją galima vertinti ir argumentuoti skirtingai. Kaip rodo urbanistikos istorija, skirtingais miesto raidos etapais priklausomai nuo vyraujančios sociokultūrinès situacijos ir ideologijos tos pačios arba panašios miesto formavimo problemos buvo sprendžiamos visiškai skirtingai.
}

Taigi bendrai estetiniai urbanistikos klausimai labai glaudžiai susiję su laikotarpio mados ir išpažistama grožio doktrina bei kanonais, kurie per laiką kinta. Todèl vertinant miesto struktūrą ir vaizdą estetiniu požiūriu, vienareikšmio, universalaus atsakymo paprastai nèra. Jei sutiktume, kad ir vienu, ir kitu atveju egzistuoja bendras grožio vardiklis (arba sutartinai galètume teigti, kad, remiantis objektyviais kriterijais, tam tikru laikotarpiu mes vertiname per laiką suformuotą urbanistinę struktūrą kaip esančią geros arba blogos estetinès kokybès), tai toks vertinimas būtų universalus. Tačiau nei bendras grožio kanonas, nei bendrinè kriterijų sistema vertinant urbanistikos kūrinių estetiką neegzistuoja. Todèl jos vertinimas iš laiko perspektyvos yra dalinis, paremtas šiandien galiojančiais grožio kanonais ir estetine doktrina ${ }^{2}$. İomu, kad skirtingais laikotarpiais miesto estetinis grožis buvo suvokiamas diametraliai priešingai (Parker 2004; Clark 2009; Wagner 2006; Bacon 1976; Hall 2002). Čia galètume palyginti naujus ankstyvojo klasicizmo miestus su jų istoriniais branduoliais - senamiesčiais, kurie tuo metu nebuvo vertinami teigiamai. Ta pati problema egzistuoja kalbant apie modernistinę urbanistiką (Le Corbusier 1987), kai tam tikru laikotarpiu šie kūriniai buvo vertinami ir dèl savo estetikos, ir dèl funkcionalumo, tačiau per pusę amžiaus kintant požiūriui i urbanistiką ir grožio sampratoms visuomeneje, šie kūriniai nebèra taip gerai vertinami kaip anksčiau. Taigi čia susidūriame su vertinimo universalumo ir kompleksiškumo problema. Reikia pažymėti, kad kompozicijos ir estetikos santykis urbanistikoje kol kas nèra kompleksiškai nagrinètas. Plačiau šia tema aptariančių darbų yra postsovietinejje erdveje ir ypač rusiškoje urbanistikos mokykloje. Paminètini tokie autoriai kaip Z. N. Jargina, Stepanova, G. I. Zosimov, Beliajeva (Яргина 1981, 1991; Степанова 2005, 2006; Зосимов 1976, 1986; Беляева 1977, 1980). Vakarų urbanistikos (Urban design) teoriniuose darbuose urbanistikos ir estetikos santykis taip pat nèra plačiau ar kompleksiškai nagrinëjamas. Šios tradicijos urbanistikoje estetika labiau yra siejama su kognityviniu ir estetiniu erdves suvokimu ir vertinimu (Cullen 1995; Salingaros 1999; Moughtin 1999, 2003; Carmona 2003).

\footnotetext{
${ }^{2}$ Galimas universalesnis kriterijus šiame diskurse galètų būti atitiktis to laikotarpio estetiniams kanonams ir etalonams. Tačiau čia atsiranda paminklosauginis aspektas, kuris nèra tiesiogiai susijęs su straipsnio objektu.
} 
1 lentelè. Kompozicijos ir estetikos santykis vertinant skirtingai suformuoto miesto struktūrą

Table 1. Relationship between composition and aesthetics in evaluation of a city structure developed in two different ways

\begin{tabular}{|l|c|c|}
\hline \multirow{2}{*}{$\begin{array}{c}\text { Urbanistinė kompozicija } \\
\text { Miesto estetika }\end{array}$} & $\begin{array}{c}\text { Kaip savitumas } \\
\text { Vyrauja natūralios raidos dèsniai, } \\
\text { artimi gamtos tvarkai }\end{array}$ & $\begin{array}{c}\text { Kaip dèsnis ir kanonas } \\
\text { Vyrauja sąmoningos veiklos dèsniai, } \\
\text { artimi fabriko tvarkai }\end{array}$ \\
\hline & $\begin{array}{c}\text { Miesto „išorès" (miestovaizdžio) ir „vidaus" grožis apibūdinamas tam tikru laikotarpiu } \\
\text { nustatytomis kaip norma estetine doktrina, mados ir grožio kanonais bei sampratomis. } \\
\text { Vyrauja subjektyvus vertinimas. Bendrinis vardiklis ir kriteriju sistema nustatomi gana } \\
\text { sunkiai. Galima bendrinè vertybine kriteriju sistema ir jos norminimas arba reguliavimas. }\end{array}$ \\
\hline
\end{tabular}

\section{Miesto kompozicijos sampratos Vakarų ir postsovietinejje urbanistikos tradicijoje}

Bendruoju atveju kompozicija yra (lot. Compositio sudèstymas, sukūrimas): meno kūrinio elementų išdèstymas, ju tarpusavio ryšys ir santykis su visuma; sandara, struktūra, konstrukcija, architektonika (Interaktyvus tarptautinių žodžių žodynas „Interleksis“). Ši apibrèžtis gerokai koreguojasi, kai kalbama apie miesto arba urbanistinę kompoziciją. Kaip jau minèta, miesto kompozicijos objektas yra susijęs su miesto struktūros ir erdvès estetikos klausimais, tačiau šio objekto samprata yra įvairialypè. Pačiu bendriausiu atveju (kalbant apie makromastelį) miesto kompozicija siejasi su miesto kaip meninès kūrybos objekto koncepcija. Šis požiūris egzistuoja seniai ir siejasi su planinga miesto formavimo veikla, skiriant dèmesị išskirtinèms miesto dalims arba ansambliams. Čia esama dvejopo požiūrio: viena vertus, miestas ir jo erdvinè bei plano sandara yra kuriami kaip vientisas kūrinys nuo pradžios iki pabaigos. Kita vertus, estetiniai kompozicijos dèsniai taikomi esamo miesto plano ir erdvinès struktūros plètrai, ją rekonstruojant arba prie jos prisiderinant. Abiem atvejais miesto kompozicija yra sudètinè planuojamo miesto įvairiapusès raidos programos dalis, kuriai, be kita ko, yra būdingi ir estetiniai požymiai. Tačiau kartu su estetinėmis kompozicijos problemomis šios veiklos procese yra sprendžiami ir funkciniai, ir techniniai - utilitarūs, ir socialiniai klausimai. Todèl dažniausiai urbanistine kompozicija yra didesnio miesto formavimo problemu komplekso dalis. Miesto kaip meninès veiklos rezultato koncepcija nuo septintojo dešimtmečio buvo aršiai kritikuojama, atkreipiant dèmesị ir ị kitas svarbias miesto formavimo problemas - socialines, kultūrines ir pan. Taip kilo reakcija ị modernistinị (Le Corbusier, F. L. Wright ir kitų) architektūrinị miesto formavimo požiūrí, o miestas kaip meninès veiklos rezultatas ir kaip autorinè koncepcija nebeteko galios. Miesto formavimas ir urbanistika tapo tarpdisciplininiu mokslu, nebesutelktu į vieną profesinę sritị.

Analizuojant su šiuo klausimu susijusius skirtingo laikotarpio literatūros šaltinius, matomos kelios esminès sampratos tradicijos: Vakarų ir postsovietinio urbanizmo tradicijos skirtumas. Samprata "miesto kompozicija“ arba „Urban Composition“ Vakarų urbanistineje literatūroje sutinkama gana retai. Dažniausiai tai menotyriniai tekstai apie miesto erdvès (Urban Space) formavimą mažesniu nei viso miesto masteliu. Dažniausiai „Urban composition“ sąvoka vartojama, kalbant apie architektūrinių ir urbanistinių kompleksu plano, erdvès kompozicijos dèsningumus bei viešąias miesto erdves. Vakarų miesto erdvès formavimo (Urban design) tradicijoje miesto ir jo daliu estetiniai klausimai itin plačiu mastu nesprendžiami. Šis objektas labiausiai siejamas su erdves suvokimo (Visual perception) ir didesnių architektūrinių ansamblių kompozicija, o sąvoka vartojama gerokai siauriau nei postsovietineje ir rusiškoje tradicijoje. Tikètina, kad tokio apibendrinto miesto kompozicijos požiūrio nebuvimas šiuolaikinëje Vakarų urbanistikoje (Urban design) yra nulemtas ilgalaikès miestų formavimo patirties, kurios viena pagrindinių sąlygų yra privati nuosavybè ir daugelio socialinių subjektų dalyvavimas miesto planavimo, formavimo procese. Tik labai retais atvejais miestas yra kuriamas kaip vientisa kompozicinè visuma (2 pav.). Daugeliu atvejų europinejje tradicijoje miesto erdvès formavimas (Urban design) siejamas su esamo miesto ar jo dalies plètra ir formavimu, atsižvelgiant i jau esančias sąlygas bei situaciją, prisitaikant prie jų. Tik atsiradus kokiems nors ypatingiems precedentams ar sąlygoms, miestas kuriamas kaip užbaigtas meninis kūrinys, tačiau tokiam žingsniui reikalingos 
a)

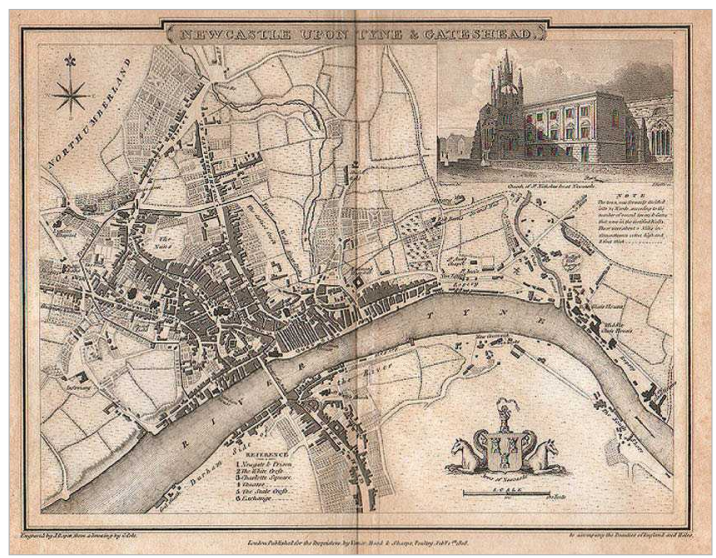

b)

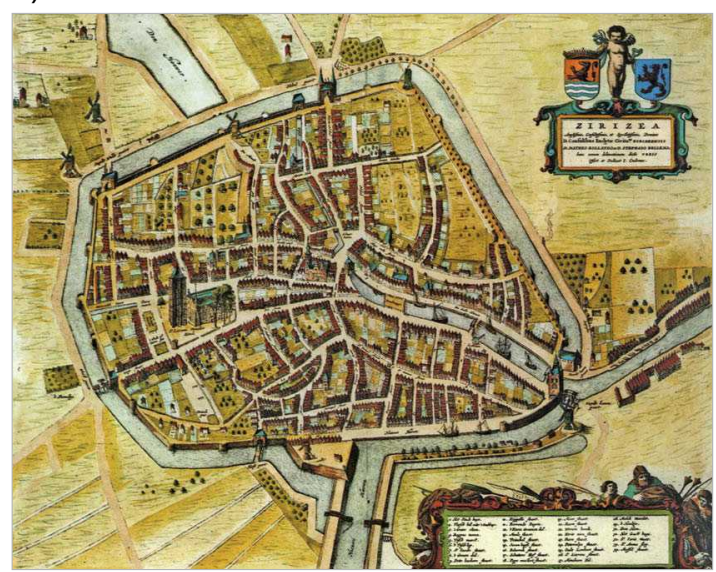

c)

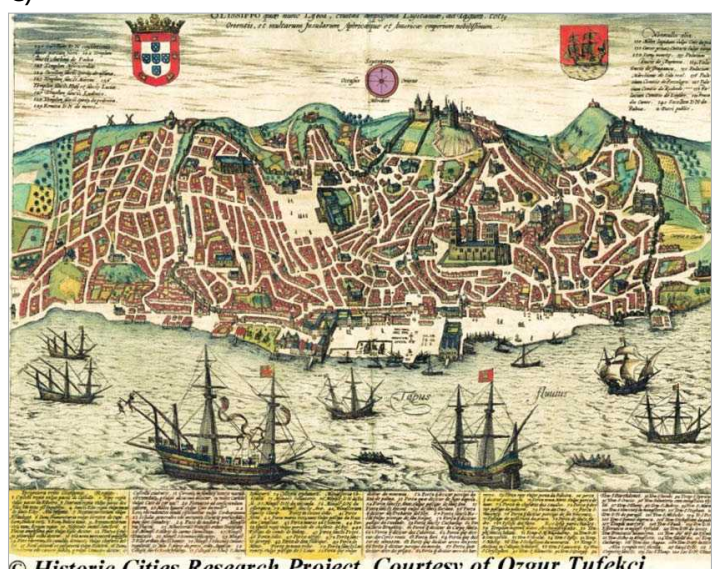

d)

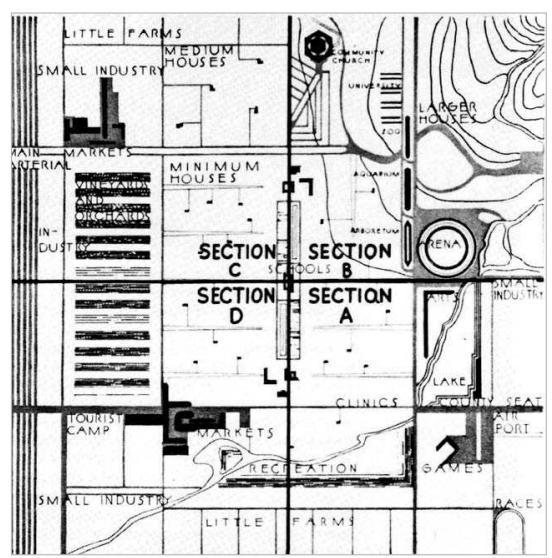

e)

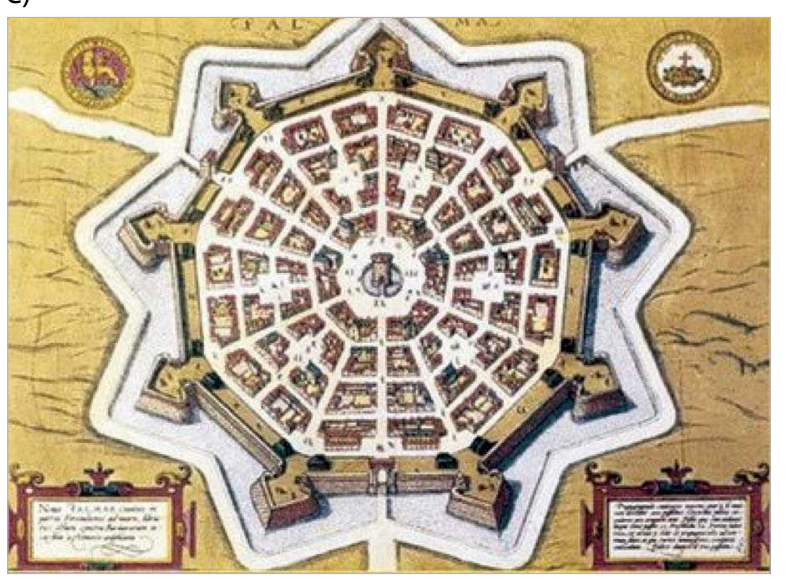

f)

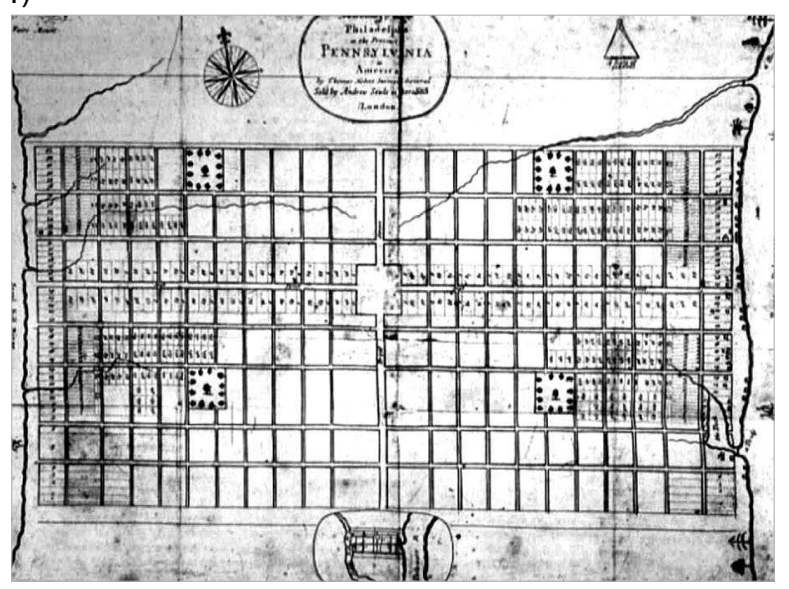

2 pav. Savaime (kaireje) susiformavusių ir planingai (dešineje) suformuotų miestu planai: a - Newcastle prie Tyne upès ir Gateshead (Jungtinè Karalystè) miesto planas, XIX a.; b - ZIERIKZEE miesto planas, XVII a., sudarytas J. Blaeu; c - Lisabonos miesto planas XVII a.; d - Frank Loyd Wright. Broadacre City' planas 1934-1935m.; e - Palmanova miesto planas, XVI a.; $\mathrm{f}$ - Filadelfijos (Pensilvanijos) valstijos miesto planas. Autorius William Penn, $1682 \mathrm{~m}$.

Fig. 2. Layouts of spontaneously developed cities (on the left) and preplanned cities (on the right): (a - New-castle upon Tyne and Gateshead (UK) town plan, the 19th century; b - ZIERIKZEE town plan made up by J.Blaeu, the 17th century; c - Lisbon city plan, the 17th century; $d$ - Frank Loyd Wright. Broadacre City plan, 1934-35; e - Palmanova town plan, the $16^{\text {th }}$ century; $\mathrm{f}$ - Filadelphia (Pensylvania) town by William Penn, 1682) 
ypatingos ir greitai pakitusios miesto raidos sociokultūrinès sąlygos ar aplinkybès (pavyzdžiui, gerokai paspartėjęs ekonominis augimas, nekilnojamojo turto plètra ir vystymas, socialinès tvarkos transformacijos ar kokie nors kiti ypatingi globalines miesto raidos sąlygas keičiantys ar veikiantys i̦vykiai ir veiksniai) ${ }^{3}$. Tačiau ir tokiais atvejais Vakarų urbanistikos tradicijoje miestas kaip kompozicinè visuma aprèpiamas ir formuojamas gana retai. Dažniausiai ir todell, kad intensyvesnis formavimas bei plètra yra telkiami i jau esamas metropolijas, kurios ir dydžiu, ir struktūra yra sudetingos, gerokai suvaržytos privačios nuosavybès bei kitų globalinių

\footnotetext{
3 Prie tokiu ivykiu galima priskirti ir olimpines žaidynes, kurios $\mathrm{XX}$ a. tapo vienu iš esminių miesto raidą veikiančių veiksnių. Neretai dèl šio ivvykio pastatomi atskiri miestu kvartalai ir dalys. Tai veiksnys, darantis itaka ne tik miestovaizdžiui, bet ir kai kada struktūrai. Tačiau ir šiais atvejais miestas kaip visuma transformuojamas itin retai. Didžiausios transformacijos pavyzdys - Pekino miestas 2008 metais. Tačiau šiuo atveju vystytojas, socialinès galios subjektase buvo valstybè. Ir tokios transformacijos imanomos tik tada, kai socialine galia yra sutelkta vieno socialinès galios subjekto rankose. Totalitarinèje visuomenejje kiti tradiciniai galios subjektai nei pačios galios, nei svertų, nei resursų veikti neturi.
}

(bendrųjų) raidos sąlygų. Tačiau taip pat pažymètina, kad ir šioje tradicijoje tiek miesto kompozicija ir jos objektas, tiek jos elementai įvardijami gana skirtingai (Rob Krier, Cliff Mougtin ir t. t.). Reikia pažymėti, kad bendrinio termino nèra, ir kaip problema šis klausimas nèra keliamas Vakarų urbanistikos tradicijoje (3-7 pav. pateikiami skirtingo laikotarpio miesto kaip užbaigto kūrinio pavyzdžiai).

Egzistuoja ir kita miesto kompozicijos samprata, būdinga modernistinei ir tarybinių laikų urbanistikos mokyklai. Tai požiūris, išlikęs iki šių dienų kai kuriose postsovietinès geopolitinès erdvės valstybėse: Lenkijoje (Wejhert 2008), Rusijoje, mažiau - Čekijoje (Hruza 1965). Čia urbanistinè kompozicijos sąvoka vartojama kur kas dažniau ir terminas yra gana polifunkciškas. Taigi urbanistinè kompozicija masteliu aprèpia ne tik viešąsias erdves ar mikrorajonus, bet ir visą miestą ar net miestų aglomeracijas ${ }^{4}$ (Vanagas 2003, 2008). Šioje

${ }^{4}$ İdomu palyginti net lietuviškojo urbanistinès tradicijos konteksto urbanistinès kompozicijos apibrèžtis. Pavyzdžiui, J. Vanago ir V. Jurkšto urbanistinès kompozicijos sampratos skiriasi iš esmès.

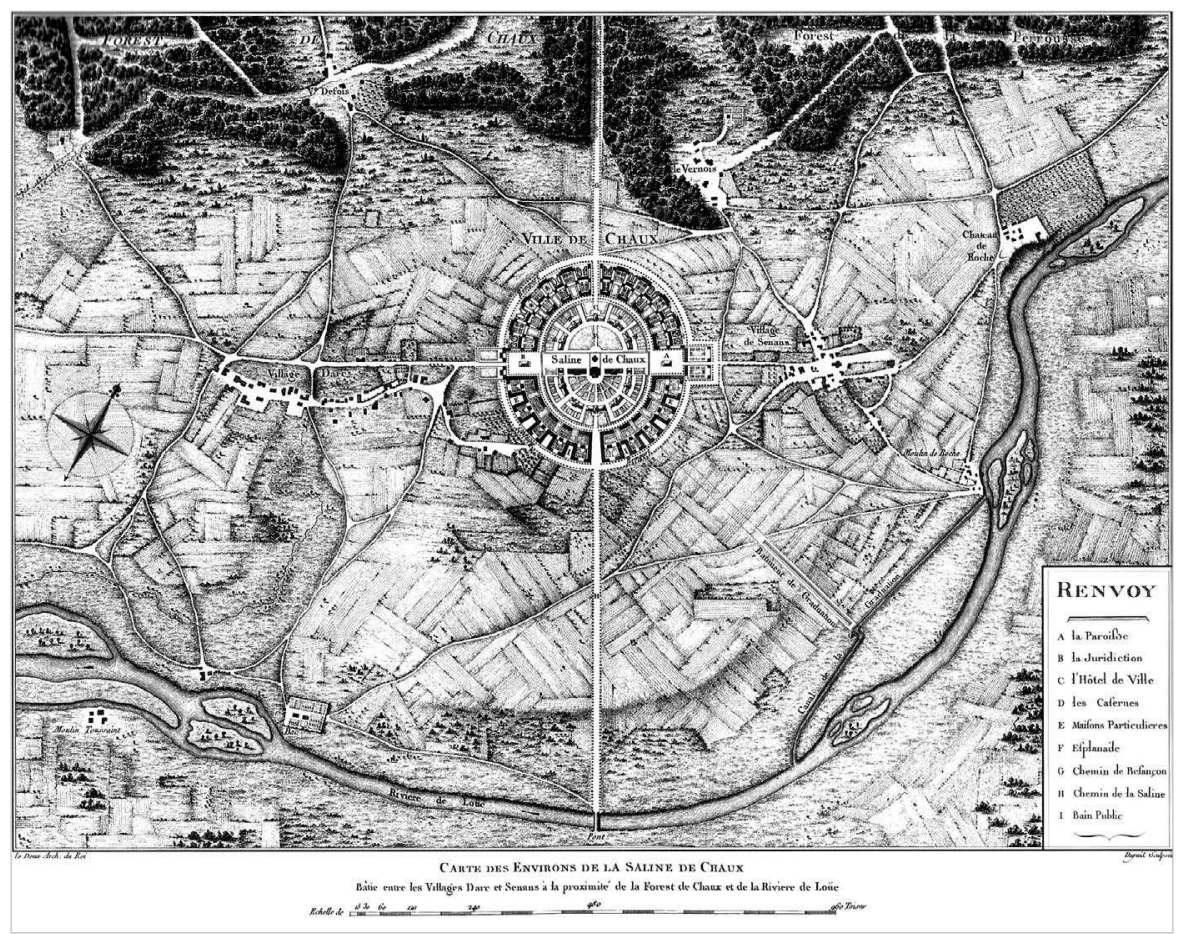

3 pav. Saline de Chaux miesto planas, 1774-1779 m. Autorius Claude Nicolas Ledoux (iš Claude-Nicolas Ledoux L'architecture considérée sous le rapport de l'art, des moeurs et de la législation. Tome premier, $1804 \mathrm{~m}$.)

Fig. 3. Saline de Chaux town plan by Claude Nicolas Ledoux (1774-79). (Sourse: Claude-Nicolas Ledoux, L'architecture considérée sous le rapport de l'art, des moeurs et de la législation. Tome premier, 1804) 


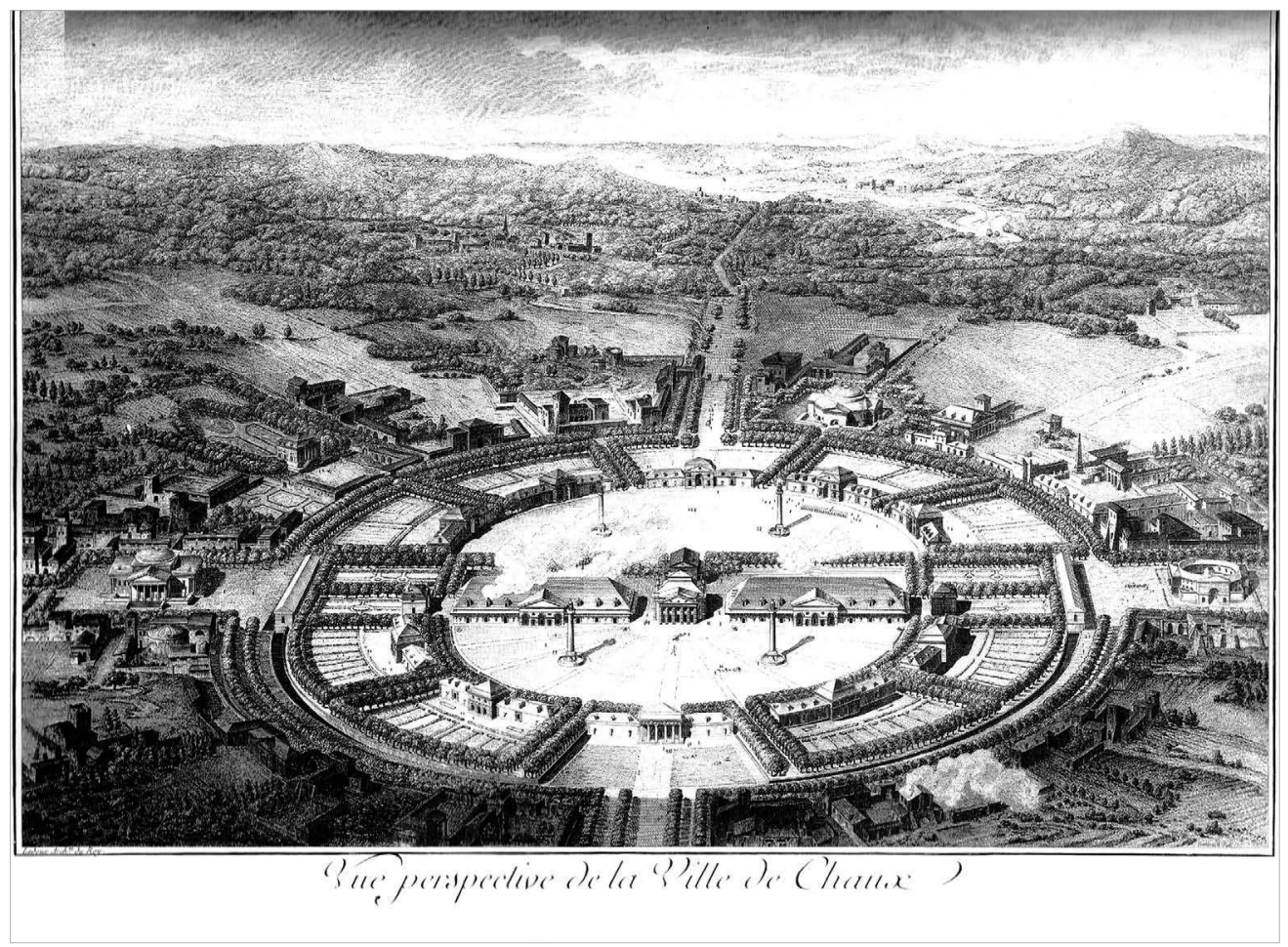

4 pav. Saline de Chaux miesto planas. Autorius Claude Nicolas Ledoux, 1774-1779 m. perspektyva (iš Claude-Nicolas Ledoux L'architecture considérée sous le rapport de l'art, des moeurs et de la législation. Tome premier, $1804 \mathrm{~m}$.)

Fig. 4. Saline de Chaux town plan by Claude Nicolas Ledoux (1774-79). (Source: Claude-Nicolas Ledoux, L'architecture considérée sous le rapport de l'art, des moeurs et de la législation. Tome premier, 1804)

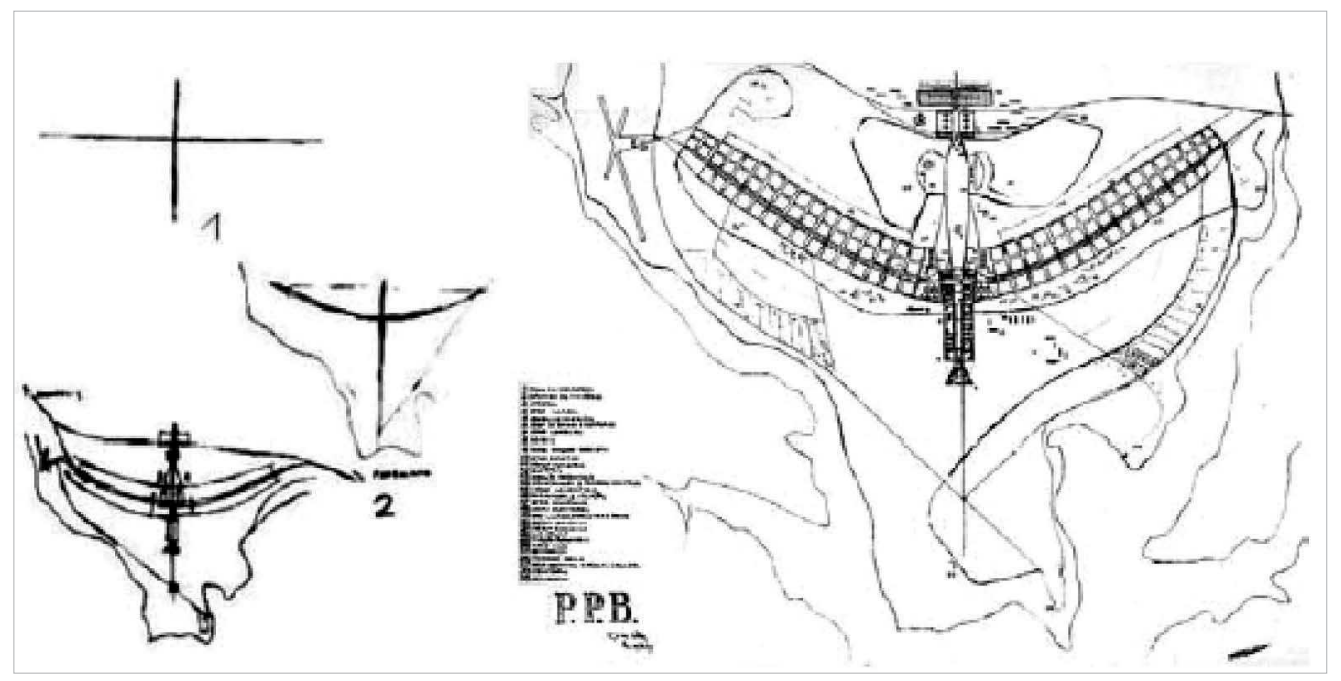

5 pav. Brazilijos miesto kompozicijos planas. Autorius Lucio Costa, $1957 \mathrm{~m}$.

Fig. 5. Brasilia (Brasil) town composition plan by Lucio Costa, 1957 


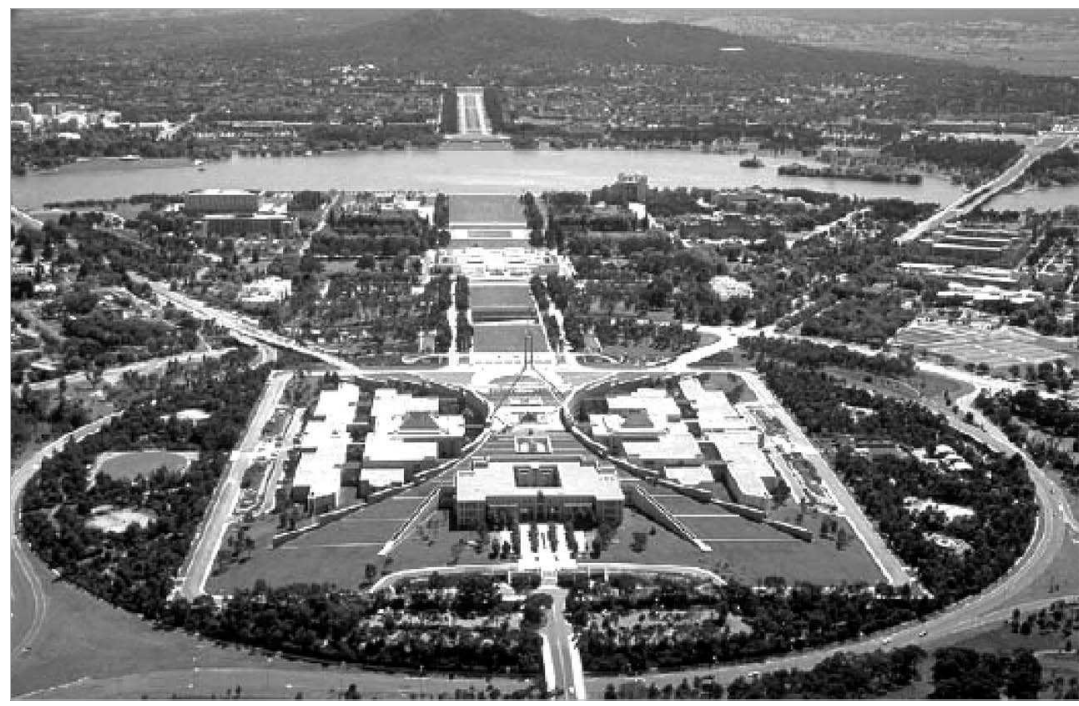

6 pav. Kanberos Parlamento rūmų vaizdas, 1988 m. Autorius Mitchell/Giurgola Architects (šaltinis: Gordon 2006)

Fig. 6. View on the Parlament House in Canberra (Australia) by Mitchell/ Giurgola Architects, 1988 (Source: Gordon 2006)

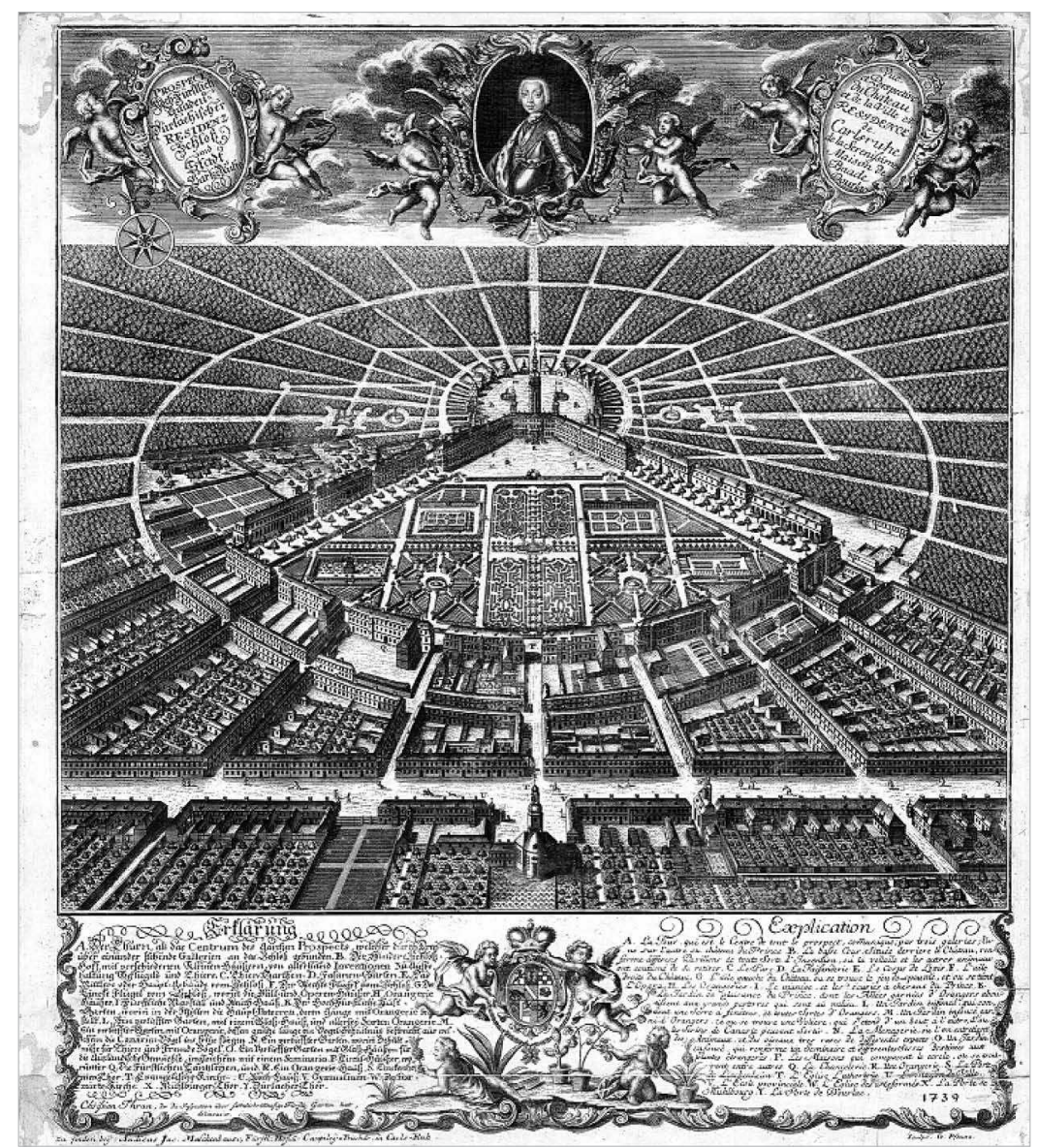

7 pav. Karlsrūhès miesto planas, 1739 m. Autorius Christian Thran

Fig. 7. Karlsruhe (Germany) town plan by Christian Thran, 1739. 
tradicijoje kompozicijai kaip meninei kūrybai skiriamas nemažas demesys. Miesto kompozicijos samprata čia apima ir vizualinio suvokimo, ir makromastelio urbanistinių struktūrų formavimo klausimus. Toks tradicijos požiūris yra suformuotas sociokultūrinio konteksto sąlygų, kai socialinès tvarkos modelis (be privačios nuosavybès) leido planingai formuoti miestus kur kas intensyviau, ir ta veikla nebuvo taip nulemta nuosavybès ar kitų tradiciniam europiniam miestui būdingų suvaržymų. Tuo metu buvo kuriami nauji pramoniniai miestai nuo pradžių iki pabaigos kaip meninès kūrybos rezultatas. Be politinio ideologinio pobūdžio ịtakų, čia svarbi buvo ir vyravusi estetinè ideologija bei utopiniai naujų miestų vaizdiniai ir ịvaizdžiai (pateikiantys socialinio gyvenimo ar kitus antropologinius ịvaizdžius kaip siekiamybę), kurie buvo realizuojami, pasitelkiant modernistinę miesto ir jo erdvės kūrimo koncepciją. Kadangi šioje urbanistikoje santykis su tradiciniu miestu buvo nevienareikšmis, apie aštuntą dešimtmetị kilo istorinių branduolių regeneracijos idejų, kuriomis remiantis buvo iš dalies sprendžiami estetiniai šios miesto dalies klausimai ir taip suformuotas gana savitas požiūris į istorines vertybes ir miesto kompoziciją. Tuomentinès regeneracijos procesą ir valdè, ir finansavo valstybè, spręsdama klausimą gana kompleksiškai, todèl atsirado istorinio branduolio tūrinés erdvinès kompozicijos ${ }^{5}$ (Jurkštas 1994, 1975, 1977) tyrimų metodų, kurie akumuliavo struktūrinès, kognityvinès ir net emocinès analizès metodus siekiant iqvertinti ir regeneruoti po Antrojo pasaulinio karo suniokotų istorinių miesto branduolių urbanistinị audinį bei vaizdą. Tačiau labai neretais atvejais, kai tradicinès nuosavybès formos veikiamas miesto modulinis tinklas - morfotipas - neegzistavo, sprendžiant regeneracijos ir harmonizavimo problemas, buvo apsiribota naujos architektūros iterpimu i tradicinę istorinio branduolio miesto struktūrą. $\mathrm{O}$ šio mastelio lygmenyje urbanistinè kompozicija sprendè estetinius bei kokybinius architektūros ir miesto audinio klausimus (K. Wejchert, V. Jurkštas, J. Hruza ir kiti). Akivaizdžiausiai šios tradicijos urbanistinès kompozicijos sampratos polifunkciškumas apibūdinamas profesoriaus J. Vanago urbanistinès kompozicijos definicijomis, pagal kurias urbanistinè kompozicija yra ir „vyksmas“, ir „urbanistinio plano organizacija“, ir „vizualinių charakteristikų visuma“, taip pat jos esmè

\footnotetext{
5 Terminas „tūrinè ir erdvinè kompozicija“ yra vertinys iš rusu kalbos (Степанов 2007). Šia kalba buvo parašyta nemažai. Vytauto Jurkšto tūrinès ir erdvinès kompozicijos samprata yra kiek platesnè nei rusiškuose šaltiniuose dèl platesnio taikomojo pobūdžio.
}

„<...> vizualinè erdvinè idèja, turinys ir būdas, kuriuo ji demonstruojama stebètojui“. Anot šio autoriaus, „urbanistinè kompozicija gali būti suprantama dviem aspektais: grynai kaip suformuota plano sandara ir kaip vizualinis suvokimas natūroje (būdas, kaip urbanistinị objektą priima stebėtojas)“. Ši apibrěžtis siejama ne tik su miesto, su jo dalies ir su mažesnio urbanistinio ansamblio estetiniu sprendiniu, bet ir su viso regiono kraštovaizdžio menine estetika (Vanagas 2008: 49). Tokia urbanistinès kompozicijos visa apimanti sąvoka būdinga tik postsovietinès urbanistikos tradicijai ${ }^{6}$, nes kitais atvejais Vakarų urbanistikos tradicijoje meninès kompozicijos šio mastelio lygmenyje niekas iš tyrinètojų ar teoretikų neįžvelgia.

\section{Apibendrinimai}

Apibendrinant būtina pabrèžti, kad miesto (arba urbanistinès) kompozicijos samprata vis dar yra platoka ir nekonkretizuota. Skirtingi teoretikai ir architektūrinès bei urbanistinès veiklos profesionalai ją vartoja skirtingai. O skirtingos urbanistinès ir miesto formavimo tradicijos šį terminą traktuoja skirtingai tiek mastelio, tiek ir svarbos miesto formavimo veiklai aspektais.

Taip pat požiūrių skirtumai yra nulemti miesto kaip meninès kūrybos objekto traktavimo urbanistikos tradicijoje ir kūrèjo autorystès galių paisymo, taip pat to, kiek priemonių ir sprendimo galios yra sukoncentruota vienose rankose. Tai modernistinio ir tradicionalistinio požiūrių prieštaravimas, kurie miesto formavimo praktikoje reiškèsi skirtingais laikotarpiais vis kitaip. Tačiau Vakarų urbanistikos (Urban design) tradicija evoliucionavo tiek, kad vieno modernistinio urbanistinio požiūrio iš esmès atsisake. Kita vertus šiame kontekste miestai vystėsi be esminių socialinès tvarkos pakitimų. Postsovietineje urbanistikos tradicijoje šis modernistinis požiūris dar vis gajus, nors esama perimamumo ir pereinamojo laikotarpio požymių. Tačiau miestų centrų plètotès pavyzdžiai Lietuvoje rodo, kad šiai raidai buvo pasirinkti ir realizuojami dar sovietiniais metais sukurti urbanistiniai konceptai, kurie ne visada koreliavo su tradicine miesto struktūra ar miestovaizdžiu. Kodèl, stipriai pasikeitus sociokultūrinio konteksto sąlygoms, miesto raidos ir

\footnotetext{
6 J. Vanagas savo vadovèlyje „Miesto teorija“ urbanistinę kompozicija ivardija dvejopai: „plačiaja prasme - urbanistinio arba teritorinio planavimo objekto plano meninė organizacija; tikslingas miesto arba jo dalies organizavimo procesas, kurio metu atsižvelgiant ị esamas ir siūlomas sąlygas, ieškoma racionalaus funkcinio, visuomeninio - ūkinio ir architektūrinio - meninio sprendinio. Siauresniaja prasme - tai kompozicinis vyksmas, kurio metu akcentuojamos meninès plastinès vertybès <...
} 
vaizdo formavimo konceptai nepakito - nèra iki galo aišku. Veikiausiai socialinès tvarkos transformacija dar nereiškia mentalinès transformacijos, o sprendžianti urbanistinès plètros klausimus konjunktūra tam tikru momentu nepakito ir idèjų bei požiūrių nebuvo pakankamai (juolab kad sprendimo galias turèjo tos pačios kartos ir urbanistinès mokyklos specialistai).

Taip pat būtina pažymèti, kad:

a) egzistuoja daug skirtingų urbanistinès arba miesto kompozicijos sampratų, kurios skiriasi tiek objekto apimti ir ribomis, tiek ir kokybinio turinio nusakymo aspektais. Terminas ir sąvoka daug dažniau bei plačiau vartojami postsovietinejje urbanistikoje, o Vakaruose jie yra kur kas siauresni;

b) galima išskirti kelias skirtingas urbanistikos tradicijas, kurios skirtingai trakruoja ir patị urbanistikos kompozicijos objektą, ir tyrimo prielaidas: tai Vakarų urbanistikos tradicija ir postsovietinè. Pirmoji dèl miesto formavimo ypatumų ir veikiamų sociokultūrinių sąlygų suformavo lokalesnị požiūrị ¿̇ miesto kaip visumos estetinị kūrimą. Antroji urbanistinè tradicija, paveikta kitokios miesto kūrimo patirties, suformavo kur kas platesnę (visa apimančią) urbanistinės kompozicijos sampratą.

\section{Literatūra}

Alexander, Ch. 1987. A New Theory of Urban Design. Oxford: Oxford University Press.

Bacon, E. N. 1976. Design of Cities: Revised Edition. Penguin (Non-Classics).

Carmona, M.; Heath, T.; Oc, T.; Tiesdell, S. 2003. Public Places-Urban Spaces. Architectural Press.

Clark, P. 2009. European Cities and Towns 400-2000. Oxford university Press.

Cullen, G. 1995. Oncise townscape. Architectural Press.

Gordon, D. 2006. Planning 20th Century Capital Cities. Routledge.

Hall, P. 2002. Cities of Tomorrow: An Intellectual History of Urban Planning and Design in the Twentieth Century. Wiley-Blackwell.

Hruza, J. 1965. Teorie Mesta. Praga (in Czech).

Interaktyvus tarptautinių žodžių žodynas „Interleksis“ [žiūrèta 201009 01]. Prieiga per internetą: <http://www. fotonija.lt/edictionaries/ui/FullDictionary.aspx $>$.

Jurkštas, V. 1975. Kauno senamiesčio tūrinè-erdvinè kompozicija, Architektūros paminklai 3: 98-120.

Jurkštas, V. 1977. Vilniaus senamiesčio tūrinè-erdvinè kompozicija, Architektūros paminklai 4: 36-57.

Jurkštas, V. 1994. Senamiesčiu regeneracija. Architektūros harmonizavimo problema. Vilnius: Technika.

Krier, L. 1995. Houses, Palaces, Cities (Architectural Design Profile), Architectural Design? Editions. New Your City.
Krier, L. 2008. Architecture: Choice or Fate: Travel Size Series. Papadakis Publishers. London.

Krier, R. 1993. Urban Space. Rizzolli. New Your City.

Krier, R. 2006. Town Spaces: Contemporary Interpretations in Traditional Urbanism. Birkhauser.

Le Corbusier. 1987. The City of To - Morrow and Its Planning. New York: Dover Publications.

Ledoux, C. N. 1804. L'architecture considérée sous le rapport de l'art, des moeurs et de la législation. Tome premier. Paris.

Lynch, K. 1960. The Image of the City. The MIT Press. Cambridge MA.

Moughtin, C. 2003. Urban Design. Street and Square. Amsterdam, Boston et al.: Architectural Press.

Moughtin, C.; Cuesta, R.; Sarris, Ch.; Signoretta, P. 1999. Urban Design: Methods and Techniques. Oxford: Architectural Press.

Parker, S. 2004. Urban Theory and Urban Experience. Routledge.

Salingaros, N. A. 1999. Urban Space and its Information Field, Journal of Urban Design 4: 29-49. doi:10.1080/13574809908724437

Vanagas, J. 2003. Miesto teorija: vadovèlis. Vilnius: Vilniaus dailès akademijos leidykla.

Vanagas, J. 2008. Urbanistikos pagrindai: vadovèlis. Vilnius: Technika. doi:10.3846/982-S

Wagner, M. 2006. The Geometries of Visual Space. Lawrence Erlbaum Associates Publishers. London.

Wejchert, K. 2008. Elementy kompozicji urbanistycznej. Warszawa: Wydawnictwo Arkady.

Беляева, Е. Л. 1977. Архитектурно-пространственная среда города как объект зрительного восприятия. Москва: Стройиздат.

Зитте, К. 1993. Художественные основы градостроительства. Москва: Стройиздат.

Зосимов, Г. И. 1976. Пространственная организация города (модуль в планировочной структуре). Москва: Стройиздат.

Степанов, А. В. и др. 2007. Объемно-пространственная композиция. Москва: Стройиздат.

Степанова, С. А. 2005. Образно-интеллектуальная сторона зрительной активности человека, в кн.: Мaтериаль всероссийской электронной заочной научнопрактической конференции «Высшая школа в период модернизации образования, опыт, проблемы, перспективы», 161-165.

Степанова, С. А. 2006. Эволюция визуального образа города, Архитектон: известия вузов №5 [interaktyvus] [žiūrèta 201009 01]. Prieiga per internetą: <http://archvuz. ru.>.

Яргина, 3. К. 1981. Градостроительный анализ. Москва: Стройиздат.

Яргина, 3. Н. 1991. Эстетика города. Москва: Стройиздат.

Яргина, 3. Н.; Косицкий, Я. В.; Владимиров, В. В.; Гутнов, А. Э.; Микулина, Е. М.; Сосновский, В. А. 1986. Основы теории градостроительства. Под ред. 3. Н. Яргиной. Москва: Стройиздат. 


\section{ABOUT THE ISSUE OF THE URBAN COMPOSITION CONCEPT}

\section{T. Grunskis}

Summary. A city nowadays has become a really complex and multi-layered structure containing the features of a phenomenon. It is a formation that has transformed or forced to rethinking many "standardized" urbanistic theories and approaches. By its shape and content it is a dynamic, constantly changing and multiple system related to other larger urban structures forming larger-scale urbanized networks. Due to such peculiarities, the city and its aesthetic qualities can no longer by judged and defined by the categories of the $19^{\text {th }}$ and $20^{\text {th }}$ centuries. Its issues and problems have long ago trespassed the boundaries of a single scientific discipline. Nevertheless, the issue of urban aesthetics and composition still remains very relevant, especially bearing in mind recent global socio-cultural conditions and the related urban unification, as, following the intense wave of urbanization, many Lithuanian towns, with the capital Vilnius preeminently, have changed a lot, both on "the outside" (cityscape) and "the inside" (local visual perception) within the last decade. Many examples of such recently transformed towns in Lithuania just testify the fact that the issue of aesthetics and composition has been almost or totally ignored in further developing or newly shaping the centers of such towns. By exploring quite a large number of foreign and Lithuanian sources of urban theory and examples of urban space and composition analysis (these are presented in the attached bibliography), the article author aims at reviewing and analyzing the categories of urban composition, its theoretical approaches and insights. This text is a presentation of interim results of the larger research. Some thesises and concepts have been also presented in different scientific conferences and publications, in the Lithuanian and English languages.

Generally speaking, the urban composition issues are directly related to the aesthetics of both urban layout structure and spatial structure. With varying sizes of cities and their separate parts, means and laws of composition applied in the cities are recognized in different ways, too. Yet, speaking about the city structure by aesthetic categories, questions of different levels (or scales) and character must be solved really often. As urban composition encompasses all these levels, its different concepts and handlings exist. They can be subjective and objective. The larger the scale of the object (urban, architectural or design piece), the less subjective aspects it contains, and vice versa, the smaller the object, the more artistic features may be found in it and thus subjectivity. Only on the urban-level scale (see Table 1.) a clear element of artistic creation appears and subjective evaluation criteria could be applied.

The other side of the problem of the urban composition notion also rests upon the fact that a city has not always been treated as a result of some artistic creation. This is especially true when speaking about the early and medieval towns, which were developing spontaneously and naturally. Signs of artistic formation are very rare and can hardly be found in the spatial structures of such towns. Particular compositional - artistic laws or canons had any influence on the formation of such towns, with functional, utilitarian requirements and the site location and socio-cultural characteristics in respect of the natural framework, socio-economic conditions, etc. standing in the first place. But could such examples be defined by the category of urban composition - this question still remains open. The key argument in discussing this issue could be the relationship between aesthetics and composition in such towns, or, in other words, how much the naturally arranged layout and spatial structure in this kind of towns is or may be aesthetical, when any artistic compositional laws have been applied to such development. Similarly, an urban structure in compliance with clear compositional laws is not necessarily aesthetical in layout and spatial structure aspects.

It is noteworthy that the relationship of composition and aesthetics so far has not been analyzed in complex. More works tackling this issue may be found in the post-soviet area, especially among Russian urban scholars. Such authors as Z. N. Yargina, S. A. Stepanova, G. I. Zosimov and E. L. Beliayeva are worth mentioning. In Western theoretical urban design works the relationship between urbanism and aesthetics has been failed to analyze in complex or at least in some broader perspective. This urban tradition relates aesthetics more to the cognitive and aesthetical perception and evaluation of space.

In the most general case (on the macro-scale) the urban composition relates to the concept of the city as an object of artistic work. This approach was developed a long time ago and relates to the city formation as preplanned activities focusing on exclusive parts of the town or ensembles. This approach is two-fold: on one hand a town and its spatial and layout structures are developed as completed piece from the beginning to the end. On the other - aesthetical composition laws are applied to the development of already existing layout and spatial structure for its reconstruction or adjustment. In both cases urban composition is a constituent part of the multiple town development program, which, inter alia, contains also some aesthetical features. Alongside the aesthetical - compositional

Table 1. Relationship between composition and aesthetics in evaluation of a city structure developed in two different ways

\begin{tabular}{|l|c|c|}
\hline Urban Composition & $\begin{array}{c}\text { Sponteanous/ Natural Development } \\
\text { As a peculiarity }\end{array}$ & $\begin{array}{c}\text { Preplanned Development } \\
\text { As a law and canon } \\
\text { Laws of premeditated development } \\
\text { prevail close to the order of the factory. }\end{array}$ \\
\hline Urban Aesthetics & $\begin{array}{c}\text { The beauty of a city "on the outside" (cityscape) and "on the inside" is defined by aesthetical } \\
\text { doctrines accepted during certain periods of time, fashion and aesthetical canons and concepts. } \\
\text { Subejctive evaluation prevails. Common denominator and criteria system could be hardly fixed. } \\
\text { Common criteria system is possible, and so is its standardization and regulation. }\end{array}$ \\
\hline
\end{tabular}


issues, this developmental process, however, covers the functional, technical - utilitarian and social problems. Therefore urban composition is usually an integral part of some larger complex of city formation problems. Analyzing the literature sources of different periods related to this question under research, a few essential traditions of the concept could be seen. Especially noticeable is the difference between the Western and post-soviet urban traditions. The notion Urban Composition could be found really rarely in Western urban literature, and usually in art criticism texts about the urban space formation on the scale smaller than the entire city. Most often the concept of Urban Composition is used speaking about the layout and space compositional regularities of architectural and urban complexes, as well as urban public spaces. In Western tradition of urban design, aesthetical issues of a city and its parts usually are not solved on especially vast scale. This object is more often related to the visual perception and composition of larger architectural ensembles, and the notion itself is used in a quite narrower sense than in post-soviet and Russian tradition. It is likely that such absence of more general approach to urban composition in modern Western urban design tradition has been determined by the long-term city formation practice with private property being one of the key conditions of such practice and participation of many subjects in the urban planning and formation processes. Only in exclusively rare cases a city is developed as a finished compositional entirety. Merely upon the occurrence of some special precedents or conditions, the city is being developed as a completed artistic piece, but this step is necessarily preceded by some special and fast changing socio-cultural urban development conditions or circumstances (such as rapid acceleration of economic growth, real estate development, social order transformations or some other special events and/or factors changing or influencing global city development conditions). Even in such special cases, the city is rarely perceived and formed as a completed compositional unit in Western urban design tradition. Usually, this is due to the fact that more intense formation and development is concentrated in the existing metropolises, which by their size and structure are complex and fairly restricted private ownership institutions with restricted global (general) development facilities. It is noteworthy, however, that in this tradition urban composition and its object and elements are defined in fairly diverse ways (Rob Krier, Cliff Mougtin, etc.). Western urban design tradition simply has no general term for this notion, and this issue has never been raised as a problem.

Different concept of urban composition was characteristic for modernist and soviet urban design tradition. The same approach still remains today in some post-soviet geopolitical areas - Poland, Russia, a little bit less in Czech Republic. The concept of urban composition is used more often here. Moreover, this term is fairly poly-functional, covering not only public spaces or urban districts, but also the entire city and even its agglomerates. This particular tradition pays a lot of attention to composition as an expression of artistic creation. The notion of urban composition covers the issues of visual perception and even formation of macro-scale urban structures. Such approach in this tradition has been formed by the socio-cultural context conditions, where the model of social order (denying any private property) allowed for the pre-planned and intense urban development, as these activities were not restricted by private property and/or other limitations present in a traditional Western European city. Alongside the political and ideological influences, the dominant aesthetical ideology and utopian brand-new city images (presenting the social life or other anthropological ideas as an objective) were considered important and realized following the Modernistic concept of the city and its space formation. Whereas in this urban tradition the main stream's relationship with a traditional city was quite ambiguous, the 1970ies saw the wave of historical core regeneration ideas, the realization of which alongside the partial solution of some aesthetical issues in this city part has formed a fairly peculiar approach towards historical values and urban composition. This regeneration process was managed and financed by the state, so the issue was tackled in a fairly complex way, therefore the exploration methods for historical core's volumetric-spatial composition were developed accumulating the methods of structural, cognitive and even emotional analysis into one whole in order to evaluate and regenerate the urban tissue and view of historical cores destroyed during the Word War II. But most often, as the city modular network morphotype influenced by traditional form of ownership simply did not exist, regeneration and harmonization problems were confined to insertion of new architecture into the traditional urban structure of the historical core. On such scale urban composition was applied to solve aesthetical - qualitative issues of architecture and urban tissue.

In summary it is noteworthy to emphasize that the concept of urban composition is still wide and remains unconcrete. It is used in different ways and for different purposes by theoreticians, as well as professional architects and urbanists. The aforementioned different urban design traditions handle this term differently, in the aspects of scale and importance within the urban development process. Such differences in the approaches have been determined by treating the city as an object of artistic creation and overemphasizing the author's powers, as well as concentrating the number of urban development instruments and solution powers in "single hands". This is a contradiction between the Modernistic and Traditional approach, which manifested differently in urban development practice, in different periods of time. The Western urban design tradition has been evolving in such a direction, where a single modernistic approach towards urban development has been essentially denied. It is significant, however, that cities in this context developed uninterrupted by any radical changes of the social order. The modernistic approach is still vital in the post-soviet urban tradition, although some signs of continuity and transitional period are obvious. Lithuanian examples of downtown developments show that urban concepts created back in the soviet times were applied and implemented in these activities, and such concepts were not always correlating with traditional city structure and/or cityscape.

Why upon such drastic transformation of conditions within the socio-cultural context urban development and image formation concepts did remain unchanged - is not fully clear. It is most likely that a transformation of social order still does not mean mental transformation. The key professional code applied for solving the urban development problems was not changed at the right moment, and a shortage of ideas and approaches was noticeable (it is noteworthy that solution powers were still left with professionals of the same generation and same urban school).

It is also significant to emphasize that:

a) A number of different concepts of urban composition exists, and they vary by the scope and boundaries of their object, as well as aspects of presentation of their qualitative content. 
The term and definition are more often and broadly used by post-soviet urbanists, whereas in the West this concept is narrower;

b) A few different urban traditions may be distinguished, which treat the same object of urban composition and research backgrounds differently. The key are the Western and postsoviet traditions of urban design. Due to certain city development peculiarities and socio-cultural conditions, the first has developed a more local approach towards the aesthetical formation of the city as entirety. The second urban design tradition influenced by absolutely different urban development experience has formed much broader (and sometimes overall) concept of urban composition.

Keywords: urban design, urban space, urban composition.

\section{TOMAS GRUNSKIS}

PhD, Assoc. Prof., Dept and Fundamentals and Theory of Architecture, Vilnius Gediminas Technical University, Pylimo g. 26/ Traku g. 1, 01132 Vilnius, Lithuania.

E-mail:grunskis@gmail.com.Web:www.grunskis.net

Publications: of author of 58 articles in popular professional and scientific magazines Research interests: urban morphology and anthropology, urban design and public space formation, interdisciplinary research. Projects: author and co-author of several winning projects in urban design and architecture. 